\title{
Skin Carcinoma
}

National Cancer Institute

\section{Source}

National Cancer Institute. Skin Carcinoma. NCI Thesaurus. Code C4914.

A carcinoma that arises from the skin. Representative examples are basal cell carcinoma and squamous cell carcinoma. 